\title{
Tree vigour influences disease susceptibility of 'Hass' avocado fruits
}

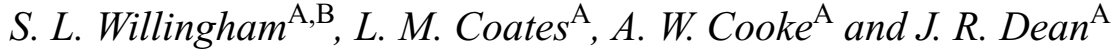 \\ ${ }^{\text {A } H o r t i c u l t u r e, ~ D e p a r t m e n t ~ o f ~ P r i m a r y ~ I n d u s t r i e s, ~} 80$ Meiers Road, Indooroopilly, Qld 4068, Australia. \\ ${ }^{\mathrm{B}}$ Corresponding author; email: sonia.willingham@dpi.qld.gov.au
}

\begin{abstract}
Differences in tree vigour as a result of feeder root destruction by Phytophthora cinnamomi were found to significantly $(P<0.05)$ influence disease susceptibility, fruit ripening rates and fruit size of 'Hass' avocado. Fruits from root rot-affected, non-vigorous trees had less anthracnose and took longer to ripen. However, they were probably unmarketable due to their small fruit size compared with fruits from healthy vigorous trees. Fruits from non-vigorous trees also had less pepper spot than vigorous trees, but only on the inside of the tree canopy. The increased disease resistance of fruits from non-vigorous trees was related to a $40 \%$ increase in the concentration of $\mathrm{Ca}$ in the fruit flesh.
\end{abstract}

Additional keywords: Colletotrichum gloeosporioides, Phytophthora, pepper spot, nutrition.

\section{Introduction}

Anthracnose, caused by the fungus Colletotrichum gloeosporioides, is the most serious postharvest disease of avocado (Persea americana). Stem-end rot, another important postharvest disease of avocado, can be caused by a number of different fungi including various Dothiorella spp., Lasiodiplodia theobromae and Phomopsis perseae. C. gloeosporioides can also cause rots at the stem-end. In this paper, the effect of tree vigour on fruit susceptibility to postharvest diseases and pepper spot in 'Hass' avocado was investigated. Pepper spot is a newly described preharvest disease that is also caused by $C$. gloeosporioides (Willingham et al. 2000).

Differences in avocado tree vigour most commonly arise from differences in Phytophthora root rot infection levels caused by the fungus Phytophthora cinnamomi. Other studies on avocado in South Africa have shown that tree vigour can have a significant impact on fruit mineral accumulation (Cutting and Bower 1990; Witney et al. 1990). Fruits from less vigorous trees were shown to have a higher concentration of $\mathrm{Ca}$, which is important for sound fruit quality (Chaplin and Scott 1980; Wills and Tirmazi 1982) and disease resistance (Conway et al. 1992). In this paper, we investigated the effects of tree vigour on mineral accumulation and disease susceptibility.

\section{Methods}

This study was conducted over two cropping seasons in a commercial orchard of avocado, cv. Hass, at Mt Tamborine in south-east Queensland. Eight or nine apparently healthy (vigorous) and eight or ten unhealthy (non-vigorous) trees in the same orchard block were selected for this study during the 1996/97 and 1997/98 seasons, respectively. The trees classified as non-vigorous had an average rating of 7 and the trees classified as vigorous had an average rating of 1 on the 0 (vigorous and healthy) to 10 (dead) scale used in Phytophthora research (Darvas et al. 1984).

Assessments of tree flowering, vegetative flushing, crop load and canopy leaf cover were made in November 1997, after fruit set and the spring vegetative flush had occurred. A rating scale of $1-5$ was used for all criteria, where $1=$ none, $2=$ light, $3=$ moderate, $4=$ heavy and $5=$ very heavy.

Prior to harvest in August 1998 (season 2), the incidence of pepper spot (percent fruit affected) was assessed in a sample of 12 fruits per tree. The aspect (north, south, east or west) and the position (inside or outside) of the fruit within the tree canopy were recorded.

In October 1997 (season 1), 20 mature fruits were harvested from each single tree replicate of each treatment (i.e. vigorous and non-vigorous). The sample size was increased to 40 fruits in August 1998 (season 2) so that the effect of fruit aspect on disease could be determined. Twenty fruits from the north side and 20 fruits from the south side of the tree were harvested in this second season. Following harvest, fruits were ripened at $22^{\circ} \mathrm{C}$ and $65 \% \mathrm{RH}$, and assessed for postharvest diseases. Fruits were assessed daily for firmness and judged ripe when soft enough to yield to gentle hand pressure. The number of days each fruit took to ripen was recorded as a measure of fruit shelf life. Ripe fruits were sliced longitudinally into quarters, peeled and examined for anthracnose and stem-end lesions. Anthracnose and stem-end lesion severity were estimated as the percentage of fruit surface area affected by either disease. The incidence of anthracnose and stem-end lesions was calculated as the percentage of fruits affected by either disease. The percent acceptable fruit was calculated as the percentage of fruits with $5 \%$ or less anthracnose severity and no stem-end lesions. The cause of lesions at the stem-end was determined by isolation onto potato-dextrose agar amended with $0.5 \%$ 
Table 1. Effect of 'Hass' avocado tree vigour on tree flowering, vegetative flushing, crop load and canopy leaf cover (1997/98 season)

\begin{tabular}{lcccc}
\hline Treatment & $\begin{array}{c}\text { Flowering } \\
(1-5)^{\mathrm{A}}\end{array}$ & $\begin{array}{c}\text { Flushing } \\
(1-5)\end{array}$ & $\begin{array}{c}\text { Crop load } \\
(1-5)\end{array}$ & $\begin{array}{c}\text { Leaf cover } \\
(1-5)\end{array}$ \\
\hline Vigorous & $4.1^{\mathrm{B}} \mathrm{a}$ & $3.3 \mathrm{a}$ & $2.1 \mathrm{a}$ & $4.2 \mathrm{a}$ \\
Non-vigorous & $3.7 \mathrm{a}$ & $2.2 \mathrm{~b}$ & $1.8 \mathrm{a}$ & $2.5 \mathrm{~b}$ \\
$\mathrm{SE}$ & 0.25 & 0.27 & 0.37 & 0.15 \\
\hline
\end{tabular}

${ }^{\mathrm{A}} \mathrm{A}$ rating scale of $1-5$ was used where $1=$ none, $2=$ light, $3=$ moderate, $4=$ heavy and $5=$ very heavy

${ }^{\mathrm{B}}$ Within columns mean values followed by the same letter are not significantly different at $P=0.05$.

streptomycin (SPDA). Cultures were incubated at $25^{\circ} \mathrm{C}$ for $\sim 2$ weeks and identified.

To measure mineral concentrations, six fruits from each of eight replicate trees were collected from the outer canopy around the tree at a uniform height $(\sim 1.5 \mathrm{~m})$. Sampling was from the vigorous and non-vigorous treatment trees at harvest in August 1998. Fruit flesh was oven dried at $60^{\circ} \mathrm{C}$ to a constant weight, ground to a fine powder using an electric coffee grinder (Philips, Groningen, The Netherlands) and digested in 5:1 (v/v) nitric-perchloric acid (Baker and Smith 1974). Total mineral nutrient concentrations were then measured by inductively coupled plasma atomic emission spectrophotometry (ICPAES).

Statistical analyses were conducted using Genstat 5 release 4.1 data analysis software (Lawes Agricultural Trust, Rothamsted Experimental Station) for a completely randomised design analysis of variance (season 1) or a split-plot design with tree replicates as whole plots split for fruit aspect (season 2). For the pepper spot data, a split-split-plot design analysis with tree replicates as whole plots split for fruit aspect and fruit position was conducted. Arcsine angular or square root transformations were made on percentage or rating data, respectively. However, examination of residual plots indicated transformation did not show improved distribution of residuals. Hence, untransformed data are presented. Pair-wise testing between means was done using the least significant difference (lsd) procedure at $P=0.05$.

\section{Results}

Non-vigorous trees assessed in late spring 1997 produced significantly $(P<0.05)$ fewer vegetative flushing terminals and had a significantly $(P<0.05)$ less dense canopy (i.e. lower leaf cover rating) than vigorous trees (Table 1). There
Table 3. Effect of tree vigour on the incidence of anthracnose and acceptable fruit in 'Hass' avocado fruits harvested from the north side and south side of the tree (1997/98 season)

\begin{tabular}{lcc}
\hline Treatment & \multicolumn{2}{c}{ Aspect } \\
& North & South \\
\hline & Anthracnose incidence $(\%)^{\mathrm{A}}$ & \\
Vigorous & $42.5^{\mathrm{B}} \mathrm{a}$ & $40.9 \mathrm{a}$ \\
Non-vigorous & $16.6 \mathrm{~b}$ & $35.5 \mathrm{a}$ \\
& Acceptable fruit $(\%)^{\mathrm{C}}$ & \\
Vigorous & $67.5 \mathrm{~b}$ & $77.6 \mathrm{ab}$ \\
Non-vigorous & $87.8 \mathrm{a}$ & $77.2 \mathrm{ab}$ \\
\hline
\end{tabular}

A Aspect standard error for comparing within a treatment is 3.99 , for all other comparisons the standard error is 7.54 .

${ }^{\mathrm{B}}$ Mean values followed by the same letter are not significantly different at $P=0.05$.

${ }^{\mathrm{C}}$ Aspect standard error for comparing within a treatment is 4.75 , for all other comparisons the standard error is 5.94 .

were, however, no significant $(P<0.05)$ differences in flowering intensity or crop load between the two treatments (Table 1).

In 1997, fruits from non-vigorous trees took significantly $(P<0.05)$ longer to ripen, had a significantly $(P<0.05)$ lower incidence of anthracnose and a higher percentage of acceptable fruit than fruits from vigorous trees (Table 2). In 1998, the same trend was apparent but the differences were not significant $(P<0.05)$. There was, however, a significant $(P<0.05)$ interaction between treatments and fruit aspect in 1998. Larger differences in anthracnose incidence and fruit acceptability (Table 3 ) were evident between treatments on the north side than the south side of the tree. Fruits from non-vigorous trees had $25 \%$ lower incidence of anthracnose and $20 \%$ more acceptable fruit (Table 3 ) than those from vigorous trees on the north side. However, similar disease incidence for anthracnose and acceptability were recorded on the south side. Although fruits from non-vigorous trees had less anthracnose and took longer to ripen, they probably could not be considered marketable due to their small fruit size (Table 2).

Table 2. The effect of tree vigour on fruit diameter, shelf life, severity and incidence of anthracnose and stem-end lesions of 'Hass' avocado fruits ripened at $22^{\circ} \mathrm{C}$ and $65 \% \mathrm{RH}$

\begin{tabular}{|c|c|c|c|c|c|c|c|}
\hline \multirow[t]{2}{*}{ Treatment } & \multirow{2}{*}{$\begin{array}{c}\text { Fruit } \\
\text { diameter } \\
(\mathrm{mm})\end{array}$} & \multirow{2}{*}{$\begin{array}{l}\text { Shelf } \\
\text { life } \\
\text { (days) }\end{array}$} & \multicolumn{2}{|c|}{ Anthracnose } & \multicolumn{2}{|c|}{ Stem-end lesions } & \multirow{2}{*}{$\begin{array}{c}\text { Acceptable } \\
\text { fruit }^{\mathrm{A}} \\
(\%)\end{array}$} \\
\hline & & & $\begin{array}{c}\text { Severity } \\
(\%)\end{array}$ & $\begin{array}{c}\text { Incidence } \\
(\%)\end{array}$ & $\begin{array}{c}\text { Severity } \\
(\%)\end{array}$ & $\begin{array}{c}\text { Incidence } \\
(\%)\end{array}$ & \\
\hline \multicolumn{8}{|c|}{ Harvested October 1997} \\
\hline Vigorous & - & $12.1^{\mathrm{B}}( \pm 0.47) \mathrm{b}$ & $33.3( \pm 5.0) \mathrm{a}$ & $95.2( \pm 1.8) \mathrm{a}$ & $10.5( \pm 1.5) \mathrm{a}$ & $72.2( \pm 5.5) \mathrm{a}$ & $7.6( \pm 4.0) b$ \\
\hline Non-vigorous & - & $13.7( \pm 0.50) \mathrm{a}$ & $30.5( \pm 4.8) \mathrm{a}$ & $88.5( \pm 1.7) b$ & $13.6( \pm 1.5) \mathrm{a}$ & $61.5( \pm 5.2) \mathrm{a}$ & $21.5( \pm 4.0) \mathrm{a}$ \\
\hline \multicolumn{8}{|c|}{ Harvested August 1998} \\
\hline Vigorous & $71( \pm 0.97) \mathrm{a}$ & $11.3( \pm 0.32) \mathrm{a}$ & $5.2( \pm 1.4) \mathrm{a}$ & $41.7( \pm 7.0) \mathrm{a}$ & $1.5( \pm 0.56) \mathrm{a}$ & $7.9( \pm 2.3) \mathrm{a}$ & $72.6( \pm 4.9) \mathrm{a}$ \\
\hline Non-vigorous & $62( \pm 0.97) b$ & $11.9( \pm 0.32) \mathrm{a}$ & $3.6( \pm 1.4) \mathrm{a}$ & $26.0( \pm 7.0) \mathrm{a}$ & $1.7( \pm 0.56) \mathrm{a}$ & $7.9( \pm 2.3) \mathrm{a}$ & $82.5( \pm 4.9) \mathrm{a}$ \\
\hline
\end{tabular}

\footnotetext{
${ }^{A}$ Acceptable fruit was calculated as the percentage of fruits with 5\% or less anthracnose severity and no stem-end lesions
}

${ }^{\mathrm{B}}$ Mean values ( \pm s.e.) within columns followed by the same letter are not significantly different at $P=0.05$. 
Table 4. The effect of tree vigour on the incidence (\%) of Dothiorella spp. (stem-end rot) and Colletotrichum gloeosporioides (anthracnose) fungal pathogens isolated from stem-end lesions of 'Hass' avocado fruits ripened at $22^{\circ} \mathrm{C}$ and $65 \% \mathrm{RH}$

\begin{tabular}{lcc}
\hline Treatment & Dothiorella spp. & $\begin{array}{c}\text { Colletotrichum } \\
\text { gloeosporioides }\end{array}$ \\
\hline & Harvested October 1997 & \\
Vigorous & $42.4^{\mathrm{A}}( \pm 5.0) \mathrm{b}$ & $21.3( \pm 5.1) \mathrm{a}$ \\
Non-vigorous & $59.3( \pm 4.7) \mathrm{a}$ & $8.2( \pm 4.8) \mathrm{a}$ \\
& Harvested August 1998 & \\
Vigorous & $60.9( \pm 17.2) \mathrm{a}$ & $16.7( \pm 7.0) \mathrm{a}$ \\
Non-vigorous & $60.0( \pm 17.2) \mathrm{a}$ & $3.1( \pm 7.0) \mathrm{a}$ \\
\hline A Mean values $( \pm$ s.e. $)$ within columns followed by the same letter are \\
not significantly different at $P=0.05$.
\end{tabular}

No significant $(P<0.05)$ differences were found between the treatments for the severity or incidence of stem-end lesions (Table 2). However, when the causal organisms of these stem-end lesions were identified and the data segregated accordingly, a significant $(P<0.05)$ difference was found between treatments for pathogen predominance. In 1997, fruits from non-vigorous trees had a significantly $(P<0.05)$ higher incidence of Dothiorella spp. at the stem-end than fruits from vigorous trees (Table 4). A general trend was evident in both seasons with stem-end rot pathogens detected more frequently than the anthracnose pathogen at the stem-end of fruits from non-vigorous trees compared to those from vigorous trees (Table 4).

On average, the incidence of pepper spot was higher on fruits positioned on the exterior of the tree canopy (outside fruits) than fruits positioned on the interior of the tree canopy (inside fruits) (Table 5). Treatment differences in pepper spot were apparent only between inside fruits, with lower incidences of pepper spot on non-vigorous inside fruits than on vigorous inside fruits (Table 5). Positional effects were also only apparent in the non-vigorous treatment, with lower incidences of pepper spot on non-vigorous inside fruits than on non-vigorous outside fruits (Table 5).

Fruits harvested from vigorous trees had a significantly $(P<0.05)$ lower $(\sim 40 \%)$ concentration of $\mathrm{Ca}$ and higher concentrations of $\mathrm{Mg}$ and $\mathrm{K}$ compared with fruits harvested from non-vigorous trees (Table 6). These differences resulted in a less favourable balance of nutrients (i.e. lower
Table 5. Effect of tree vigour on the incidence of pepper spot on 'Hass' avocado fruits positioned on the inside and outside of the tree canopy (1997/98 season)

\begin{tabular}{|c|c|c|c|}
\hline \multirow[t]{2}{*}{ Fruit position } & \multicolumn{2}{|c|}{ Treatment } & \multirow[t]{2}{*}{ Row mean } \\
\hline & Vigorous & Non-vigorous & \\
\hline Inside & $96.6^{\mathrm{A}}( \pm 3.2) \mathrm{a}$ & $83.4( \pm 3.4) b$ & $90.4( \pm 2.5) \mathrm{B}$ \\
\hline Outside & $98.9( \pm 3.2) \mathrm{a}$ & $100.0( \pm 3.4) \mathrm{a}$ & $99.4( \pm 2.5) \mathrm{A}$ \\
\hline
\end{tabular}

${ }^{\mathrm{A}}$ Mean values ( \pm s.e.) followed by the same case letter are not significantly different at $P=0.05$

$\mathrm{Ca}+\mathrm{Mg} / \mathrm{K}$ ratio and higher $\mathrm{K} / \mathrm{Ca}$ ratio, Table 6). No significant $(P<0.05)$ differences in percentage flesh dry matter were evident between the two treatments (Table 6).

\section{Discussion}

Tree vigour was found to significantly impact on disease susceptibility. The increased disease resistance to anthracnose and longer shelf life of fruits from the non-vigorous trees may have been due to their higher concentration of $\mathrm{Ca}$ and more favourable balances of mineral nutrients, in particular the higher ratio of $\mathrm{Ca}+\mathrm{Mg} / \mathrm{K}$.

Fruit mineral nutrition, especially $\mathrm{Ca}$, is very important for sound fruit quality (Chaplin and Scott 1980; Wills and Tirmazi 1982). High fruit $\mathrm{Ca}$ concentration has been correlated with low levels of postharvest disease in apple (Conway and Sams 1983, 1984, 1987; Sams et al. 1993; Conway et al. 1999), peach (Conway et al. 1987) and avocado (Hofman et al. 1999). The ability of $\mathrm{Ca}$ to retard ripening and senescence and reduce the postharvest development of diseases is thought to be due to strengthening of cell walls and maintenance of membrane selective permeability and integrity (DeMarty et al. 1984). Calcium strengthens cell walls by cross-linking the pectic polymers in the cell wall and middle lamella (Carpita and Gibeaut 1993), thereby making them less accessible to attack by fungal pectolytic enzymes (Bateman and Lumsden 1965; Stockwell and Hanchey 1982; McGuire and Kelman 1986; Conway et al. 1992). Restricting tissue maceration and the subsequent release of free $\mathrm{Ca}^{2+}$ ions from the cell wall may also reduce decay by preventing host signalling and the activation of enzymes involved in pathogenesis (Pagel and Heitefuss 1990).

Table 6. The effect of tree vigour on fruit flesh mineral concentrations ( $/$ / kg FW) and percentage dry matter (DM) of 'Hass' avocado fruits harvested in August 1998

\begin{tabular}{lcccccc}
\hline Treatment & $\mathrm{Ca}$ & $\mathrm{Mg}$ & $\mathrm{K}$ & $\mathrm{Ca}+\mathrm{Mg} / \mathrm{K}$ & $\mathrm{K} / \mathrm{Ca}$ & $\% \mathrm{DM}$ \\
\hline Vigorous & $76.7^{\mathrm{A}} \mathrm{b}$ & $269.3 \mathrm{a}$ & $4150 \mathrm{a}$ & $0.09 \mathrm{~b}$ & $65.5 \mathrm{a}$ & $27.2 \mathrm{a}$ \\
Non-vigorous & $127.6 \mathrm{a}$ & $253.1 \mathrm{~b}$ & $3672 \mathrm{~b}$ & $0.11 \mathrm{a}$ & $30.1 \mathrm{~b}$ & $28.3 \mathrm{a}$ \\
$\mathrm{SE}$ & 4.8 & 5.2 & 120 & 0.004 & 3.5 & 0.6 \\
\hline
\end{tabular}

${ }^{\mathrm{A}}$ Mean values within columns followed by the same letter are not significantly different at $P=0.05$. 
Fruits from the more vigorous trees possibly had a lower concentration of $\mathrm{Ca}$ due to the presence of more vegetative shoots which can out-compete fruits for $\mathrm{Ca}$ (Kirkby and Pilbeam 1984; Ho et al. 1993). Similar reductions in fruit Ca accumulation from more vigorous avocado trees were observed by South African researchers (Cutting and Bower 1990; Witney et al. 1990). However, Cutting and Bower (1990) were unable to relate the reduced fruit $\mathrm{Ca}$ accumulation in more vigorous trees to any significant changes in fruit quality, such as an increase in physiological storage disorders. The observed effect of tree vigour on fruit size in this study may have also been contributing to the higher concentration of $\mathrm{Ca}$ in smaller fruits from non-vigorous trees. An inverse curvilinear relationship between fruit $\mathrm{Ca}$ concentration and mean fruit mass has been shown to exist in apple (Perring 1979). In mango, an increase in tree vigour, associated with an increase in the leaf to fruit ratio, has been shown to cause a significant reduction in fruit $\mathrm{Ca}$ accumulation and an increase in postharvest disease susceptibility (Simmons et al. 1998).

Fruits from non-vigorous trees were also found to be less susceptible to pepper spot, but only on the inside of the tree canopy. This observation was most likely because the incidence of pepper spot was, on average, lower on the inside of the tree. Inside fruits were shaded and less sunburnt, which can exacerbate pepper spot (Willingham et al. 2000). Thus, larger treatment differences were evident. Pepper spot may be more prevalent on fruits positioned on the sunny exposed side of the tree as the fruits natural defences may be compromised in stressed tissue (Joyce et al. 1998).

The increase in the presence of stem-end rot fungi in non-vigorous fruits may have been due to the significant reduction in vegetative flushing. Any factor that reduces the vegetative growth of a tree, such as water stress, has been hypothesised to favour the colonisation of the fruit pedicels and stem-end tissue by endophytic stem-end rot fungi (Pusey 1989). Although, endophytic colonisation of avocado fruit stem-end tissue has not been proven, it is believed that an infection process occurs in avocado similar to that shown in mango (Johnson et al. 1992).

This study has demonstrated that factors that influence mineral (particularly Ca) accumulation into the fruit such as differences in tree vigour due to root rot, can have a significant impact on anthracnose and pepper spot susceptibility. Canopy density was also shown to be an important factor for pepper spot development as less pepper spot was observed on fruits positioned on the inside of the tree canopy of non-vigorous trees compared to vigorous trees. These fruits would be less sun-stressed but also in conditions that were perhaps less conducive (i.e. reduced humidity due to less dense canopy) for spore germination and infection.

\section{Acknowledgements}

We thank the Australian Avocado Growers Federation, Horticulture Australia Limited and the Queensland Horticulture Institute for funding this project.

\section{References}

Baker AS, Smith RL (1974) Preparation of solutions for atomic absorption analyses of $\mathrm{Fe}, \mathrm{Mn}, \mathrm{Zn}$, and $\mathrm{Cu}$ in plant tissue. Journal of Agricultural and Food Chemistry 22, 103-107.

Bateman DF, Lumsden RD (1965) Relation of calcium content and nature of the pectic substances in bean hypocotyls of different ages to susceptibility to an isolate of Rhizoctonia solani. Phytopathology 55, 734-738

Carpita NC, Gibeaut DM (1993) Structural models of primary cell walls in flowering plants: consistency of molecular structure with the physical properties of the walls during growth. The Plant Journal 3, 1-30. doi:10.1046/J.1365-313X.1993.00999.X

Chaplin GR, Scott KJ (1980) Association of calcium in chilling injury susceptibility of stored avocados. HortScience 15, 514-515.

Conway WS, Greene GM, Hickey KD (1987) Effects of preharvest and postharvest calcium treatments of peaches on decay caused by Monilinia fructicola. Plant Disease 71, 1084-1086.

Conway WS, Jansiiewicz WJ, Klein JD, Sams CE (1999) Strategy for combining heat treatment, calcium infiltration, and biological control to reduce postharvest decay of 'Gala' apples. HortScience 34, 700-704

Conway WS, Sams CE (1983) Calcium infiltration of Golden Delicious apples and its effect on decay. Phytopathology 73, 1068-1071.

Conway WS, Sams CE (1984) Possible mechanisms by which postharvest calcium treatment reduces decay in apples. Phytopathology 74, 208-210.

Conway WS, Sams CE (1987) The effects of postharvest infiltration of calcium, magnesium, or strontium on decay, firmness, respiration, and ethylene production in apples. Journal of the American Society for Horticultural Science 112, 300-303.

Conway WS, Sams CE, McGuire RG, Kelman A (1992) Calcium treatment of apples and potatoes to reduce postharvest decay. Plant Disease 76, 329-334.

Cutting JGM, Bower JP (1990) Spring vegetative flush removal: the effect on yield, size, fruit mineral composition and quality. South African Avocado Growers' Association Yearbook 13, 33-34.

Darvas JM, Toerien JC, Milne DL (1984) Control of avocado root rot by trunk injection with phosethyl-Al. Plant Disease 68, 691-693.

Demarty M, Morvan C, Thellier M (1984) Calcium and the cell wall. Plant, Cell and Environment 7, 441-448.

Ho LC, Belda R, Brown M, Andrews J, Adams P (1993) Uptake and transport of calcium and the possible causes of blossom-end rot in tomato. Journal of Experimental Botany 44, 509-518.

Hofman P, Whiley T, Marques R (1999) Fruit quality and nutrition-the role of rootstocks. Talking Avocados 10, 26-27.

Johnson GI, Mead AJ, Cooke AW, Dean JR (1992) Mango stem end rot pathogens - fruit infection by endophytic colonisation of the inflorescence and pedicel. The Annals of Applied Biology 120, 225-234.

Joyce DC, Johnson GI, Gosbee MJ (1998) Does preharvest stress of plants affect postharvest decay of their fruit? In 'Disease resistance in fruit'. (Eds GI Johnson, E Highley, DC Joyce) $A C I A R$ Proceedings 80, 39-45.

Kirkby EA, Pilbeam DJ (1984) Calcium as a plant nutrient. Plant, Cell and Environment 7, 397-405. 
McGuire RG, Kelman A (1986) Calcium in potato tuber cell walls in relation to tissue maceration by Erwinia carotovora pv. atroseptica. Phytopathology 76, 401-406.

Pagel W, Heitefuss R (1990) Enzyme activities in soft rot pathogenesis of potato tubers: effects of calcium, $\mathrm{pH}$ and degree of pectin esterification on the activities of polygalacturonase and pectate lyase. Physiological and Molecular Plant Pathology 37, 9-25.

Perring MA (1979) The effects of environment and cultural practices on calcium concentration in the apple fruit. Communications in Soil Science and Plant Analysis 10, 279-293.

Pusey PL (1989) Influence of water stress on susceptibility of nonwounded peach bark to Botryosphaeria dothidea. Plant Disease 73, 1000-1003.

Sams CE, Conway WS, Abbott JA, Lewis RJ, Ben-Shalom N (1993) Firmness and decay of apples following postharvest pressure infiltration of calcium and heat treatments. Journal of the American Society for Horticultural Science 118, 623-627.

Simmons SL, Hofman PJ, Whiley AW, Hetherington SE (1998) Effects of leaf:fruit ratios on fruit growth, mineral concentration and quality of mango (Mangifera indica L. cv. Kensington Pride). The Journal of Horticultural Science and Biotechnology 73, 367-374.
Stockwell V, Hanchey P (1982) Cytohistochemical techniques for calcium localization and their application to diseased plants. Plant Physiology 70, 244-251.

Willingham SL, Cooke AW, Coates LM, Pegg KG (2000) Pepper spot: A new preharvest Colletotrichum disease of avocado cv. Hass. Australasian Plant Pathology 29, 151. doi:10.1071/AP00025

Wills RBH, Tirmazi SIH (1982) Inhibition of ripening of avocados with calcium. Scientia Horticulturae 16, 323-330. doi:10.1016/03044238(82)90031-0

Witney GW, Hofman PJ, Wolstenholme BN (1990) Effect of cultivar, tree vigour and fruit position on calcium accumulation in avocado fruits. Scientia Horticulturae 44, 269-278. doi:10.1016/03044238(90)90127-Z

Received 15 November 2001, accepted 15 July 2003 